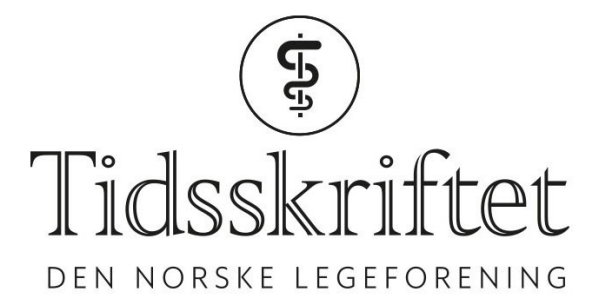

\title{
En jente med slapphet og alvorlige elektrolyttforstyrrelser
}

NOE Å LAERE AV

\section{SVERRE SIGURD LAMENS}

E-post: sverre_sigurd@hotmail.com

Barne- og ungdomsklinikken

St. Olavs hospital

Sverre Sigurd Lamens er lege i spesialisering i barnesykdommer.

Forfatteren har fylt ut ICMJE-skjemaet og oppgir ingen interessekonflikter.

\section{MAGNUS AASSVED HJORT}

Barne- og ungdomsklinikken

St. Olavs hospital

Institutt for klinisk og molekylær medisin

NTNU

Magnus Aassved Hjort er lege i spesialisering i barnesykdommer, konstituert overlege og førsteamanuensis.

Forfatteren har fylt ut ICMJE-skjemaet og oppgir ingen interessekonflikter.

En jente i tidlig barneskolealder ble innlagt ved barneavdelingen etter akutt debut av svimmelhet, nummenhet i høyre arm og ordletingsvansker. Symptomene hadde gått tilbake ved innkomst, men det skulle likevel vise seg at jenta var alvorlig syk.

Jenta var fra tidligere plaget med forstoppelse, hyperreaktive luftveier og ble fulgt av tannlege for hypomineraliserte tannemaljer. I tillegg var hun ekstremt redd for helsepersonell, noe foreldrene mistenkte kom av tidligere fors $\varnothing \mathrm{k}$ på blodprøvetaking. Ti uker før det aktuelle hadde hun hatt en episode med forkjølelse som foreldrene beskrev som kraftigere enn vanlig. Etter dette hadde hun aldri kommet seg helt og var slapp med behov for mye hvile. De hadde vært hos fastlege for vurdering, men på grunn av angsten for helsepersonell måtte de avbryte fors $\emptyset \mathrm{k}$ på blodprøvetaking to ganger.

Innleggelsesdagen fikk jenta akutt debut av ordletingsvansker, nummenhet i høyre arm og svimmelhet i en slik grad at hun falt over under lek. Symptomene gikk tilbake, men etter kort tid fikk hun på nytt ordletingsvansker. Da hun kom til barnemottaket 2,5 timer etter debut, hadde symptomene gått helt tilbake. Hun gikk, pratet, spiste og drakk, men var svært trett og ville bare sove. Hennes angst hindret fullstendig undersøkelse, hun snudde seg unna, lå på magen og nektet å samarbeide. Vitalparametre og auskultasjon av hjerte, lunger og buk var normale. Nevrologisk var hun vanskelig å vurdere på grunn av manglende samarbeidsvilje. Det var symmetrisk og normal ansiktsmimikk, pupillreaksjon og bevegelse av ekstremiteter. Det ble forsøkt med midazolamrus for å få tatt blodprøver, men hun motsatte seg alle forsøk på medisinering. Hun opplevde situasjonen som stressende, begynte å hyperventilere og nektet å høre på noen, inkludert foreldrene, hver gang 
helsepersonell kom i nærheten.

Flere ulike differensialdiagnoser ble overveid på dette tidspunktet. På grunn av tilbakegang av symptomer og mangel på klare funn, ble infarkt, blødning eller tumor ansett som lite sannsynlig, selv om forløpet av slike cerebrale hendelser kan være fluktuerende. Transitorisk iskemisk attakk eller epilepsi kunne passet med tanke på varigheten og tilbakegangen av symptomer. En annen årsak til cerebrale symptomer hos barn er hypoglykemi. For å kunne utrede ytterligere hadde det vært nødvendig med tvang, men dette kunne etter vår vurdering ha forverret situasjonen for jenta, noe vi ikke ønsket. Situasjonen var uavklart, men pasienten framstod som stabil. Hun ble derfor lagt inn til observasjon over natten for videre utredning neste dag.

Om morgenen da foreldrene skulle vekke jenta, var hun påfallende blek, klam og ikke kontaktbar. Det var ingen reaksjon på smertestimuli, hun hadde lett surklete pust, normal saturasjon og puls. Pupillene var dilaterte, men reagerte på lys. Det ble slått alarm for å tilkalle mer personale. Like etter fikk pasienten et generalisert tonisk-klonisk anfall som ble kupert med midazolam administrert bukkalt.

Årsaker til krampeanfall hos barn kan klassifiseres som strukturelle, genetiske, infeksiøse, metabolske, immunologiske eller idiopatiske (1). Feberkramper er en vanlig kontaktårsak i barnemottak, men vår pasient var ikke infeksjonspreget, og feberkramper er dessuten vanligst hos barn yngre enn fem år (2). På grunn av krampeanfallet og symptomene dagen før ble det nå ansett som nødvendig å utelukke strukturelle årsaker som tumor, blødning eller infarkt samt infeksjon, elektrolyttforstyrrelse eller metabolsk årsak.

I den postiktale fasen ble det tatt kapillær glukose som var 1,7 mmol/l (referanseområde 4,0-6,3 mmol/l), og det ble umiddelbart startet med intravenøs glukose mot hypoglykemien. Pasienten ble lagt i narkose for akutt MR caput og samtidig blodprøvetaking. MR caput viste asymmetri i de cerebrale venene, som mulig anatomisk variant, eventuelt uttrykk for hyperemi etter krampeanfall. Utover dette var det normale funn.

Blodprøvene viste at det i tillegg til hypoglykemi forelå både metabolsk acidose med $\mathrm{pH}$ 7,10 $(7,32-7,43)$ og bikarbonat $16 \mathrm{mmol} / \mathrm{l}(24-31 \mathrm{mmol} / \mathrm{l})$ samt elektrolyttforstyrrelser med hypoosmolalitet (258 mosmol/ $\mathrm{kg}(289-305))$ hyponatremi (119 mmol/l (137-145)), hypokalsemi (fritt kalsium 1,01 mmol/l (1,18-1,32)) og hyperfosfatemi (3,00 mmol/l $(1,00-1,80))$. Pasienten ble overflyttet til barneintensivavdeling, hvor det ble startet med korreksjon av elektrolytter med intravenøs væske med tilsetninger etter retningslinjer i Akuttveileder i pediatri $(3,4)$.

MR caput utelukket strukturelle årsaker, mens de uttalt patologiske elektrolyttverdiene kunne forklare symptomene hennes. Kramper kan utløses av både hypoglykemi, hyponatremi og hypokalsemi (5). Det er spesielt viktig å undersøke kalsium ved nummenhet og krampetendens. Pasienten framstod som euvolem. SIADH-syndrom som innebærer $ø$ kt utskilling av antidiuretisk hormon (syndrome of inappropriate antidiuretic hormone secretion), glukokortikoidmangel, stress eller hypotyreose ble derfor ansett som mulige forklaringer på elektrolyttforstyrrelsene. Av disse var binyrebarksvikt mest sannsynlig, noe som også kunne forklare acidosen. Hun var imidlertid ikke hypotensiv eller hyperkalemisk.

Narkosen ble seponert, men pasienten var fortsatt påfallende slapp. Ytterligere blodprøvesvar viste lavt kortisolnivå på $6 \mathrm{nmol} / \mathrm{lom}$ morgenen (133-537), som bekreftet mistanken om binyrebarksvikt. Det ble lagt merke til at hun hadde generell hyperpigmentering, men ikke i aksiller eller slimhinner. Det ble etter retningslinjer i Akuttveileder i pediatri startet med hydrokortison $100 \mathrm{mg}$ intravenøst, etterfulgt av $100 \mathrm{mg}$ intravenøst over de neste 24 timene (6). Pasienten våknet gradvis til i løpet av noen timer, og dagen etter var hun seg selv igjen.

Hyperpigmentering er et karakteristisk funn ved primær binyrebarksvikt, fordi adrenokortikotropt hormon (ACTH) også stimulerer produksjonen av melanin. Dette viste 
seg å være tilfellet hos jenta, som hadde en ACTH-verdi på 228 pmol/l (1,1-10,2). Pasientens binyrebarksvikt kunne forklare acidose, hyponatremi og hypoglykemi, men ikke hyperfosfatemi og hypokalsemi. Kalsium- og fosfatbalansen styres i stor grad av paratyreoideahormon (PTH). PTH øker nivået av ekstracellulært kalsium og er den viktigste regulatoren av kalsiumnivået. Det virker også på regulering av fosfat ved å øke utskillelsen i nyrene. Vår pasient viste seg å ha under målbart nivå av PTH (<0,5 pmol/l (2,3-10,7 pmol/l)), forenlig med hypoparatyreoidisme. Dette forklarte dermed både hennes hyperfosfatemi og hypokalsemi. Akutt binyrebarksvikt og hypoparatyreoidisme er sjeldne sykdommer hos barn. At vår pasient hadde begge sykdommene, ga mistanke om en felles årsak, hvorav autoimmunitet er klart vanligst.

På mistanke om autoimmunt polyendokrint syndrom type 1 (APS-1) ble det tatt en genprøve som ved sekvensering av regulatorgenet AIRE avslørte heterozygoti for to patologiske varianter, henholdsvis c.22C>T, p.(Arg8Cys) og c.1163_1164insA, p.(Met388,IlefsTer36) (Medisinsk genetikk, Haukeland universitetssjukehus). Videre utredning avdekket også at hun hadde antistoffer mot parietalceller på $32 \mathrm{U} / \mathrm{ml}$ (o-10 U/ml), intrinsisk faktor $357 \mathrm{U} / \mathrm{ml}$ (o-10 U/ml), forhøyet anti-TPO på $41 \mathrm{IE} / \mathrm{ml}$ (o-35 IE/ml) og autoantistoff mot binyrebark (titer $>640$, positiv) (Avdeling for immunologi og transfusjonsmedisin, St. Olavs hospital). Positive autoantistoffer ble videre bekreftet med analyse av antistoff mot endokrint vev (Avdeling for immunologi og transfusjonsmedisin, Oslo universitetssykehus) som også inneholder antistoff mot gonader (>100, positiv). Alle disse funnene støttet opp om diagnosen.

Under sykehusinnleggelsen hadde hun flere episoder med diaré. Det ble derfor gjennomført en gastroskopi, som viste autoimmun kronisk atrofisk gastritt. Hun ble utskrevet etter fire uker og er nå tilbake i habitualtilstand. Hun følges med regelmessige kontroller og behandles med kortisonacetat, fludrokortison, alfakalsidol (vitamin $\mathrm{D}_{3}$ preparat), kalsium, og vitamin D-dråper. Hun er henvist til endokrinologisk avdeling ved Haukeland universitetssjukehus, som driver Registeret for organspesifikke autoimmune sykdommer (ROAS) og har spesifikk interesse for autoimmunt polyendokrint syndrom type 1.

\section{Diskusjon}

Autoimmunt polyendokrint syndrom type 1 er en sjelden sykdom med autosomalt recessiv arvegang, som tidligere er beskrevet i Tidsskriftet hos en voksen pasient (7). Syndromet er en autoimmun sykdom som skyldes en defekt i autoimmunregulatorgenet AIRE (8). AIREgenet uttrykker tusenvis av vevsspesifikke selvantigen i thymus, slik at autoreaktive T-celler blir destruert via negativ seleksjon. En mutasjon i dette genet vil føre til at autoreaktive Tceller unngår apoptose (9). Videre spekuleres det $i$ at AIRE-genet er involvert i utviklingen av Foxp3+ regulatoriske T-celler som kan undertrykke autoreaktive T-celler (8-10). Dermed kan en slik defekt medføre at autoreaktive T-celler unngår destruksjon og at man får nedsatt danning av regulatoriske T-celler, som normalt ville undertrykt autoreaktive T-celler. Hos pasientene gjenfinnes både sirkulerende autoantistoffer og infiltrerende lymfocytter i de affiserte organene, som til slutt vil medføre organsvikt $(9,11)$. Forekomsten på verdensbasis er estimert til 1:100 ooo, i Norge til 1: 90 ooo, mens i Finland og blant persiske jøder er forekomsten så høy som henholdsvis 1:25000 og 1: 9000 (9,12-14).

Klinisk kjennetegnes autoimmunt polyendokrint syndrom type 1 av en klassisk triade med kronisk mukokutan candidiasis, hypoparatyreoidisme og binyrebarksvikt (15). Sykdommen kan ha en variabel presentasjon med en rekke andre sykdomsmanifestasjoner (figur 1) ( 7 , 16). I en norsk studie hadde 52 pasienter med sykdommen i median fem manifestasjoner (11). Det er vanlig at første manifestasjon debuterer i barndommen, der mukokutan candidiasis inntrer først, før hypoparatyreoidisme og binyrebarksvikt (17). I den norske studien var imidlertid hypoparatyreoidisme noe vanligere enn kronisk mukokutan candidiasis som første manifestasjon, og $40 \%$ av pasientene utviklet hele triaden (11). I en finsk studie var mukokutan candidiasis den første presentasjonen, og $23 \%$ av pasientene 
hadde 1-6 andre manifestasjoner før de utviklet den klassiske triaden (15).

Tannemaljehypoplasi, slik også vår pasient hadde, er et tidlig funn hos mange (11,18). Det er beskrevet at tidlig debut av sykdommen fører til et mer alvorlig forløp, med flere manifestasjoner (11). Dette viser at sykdommen har stor fenotypisk variasjon, som kan føre til sen oppdagelse og forsinket behandling.

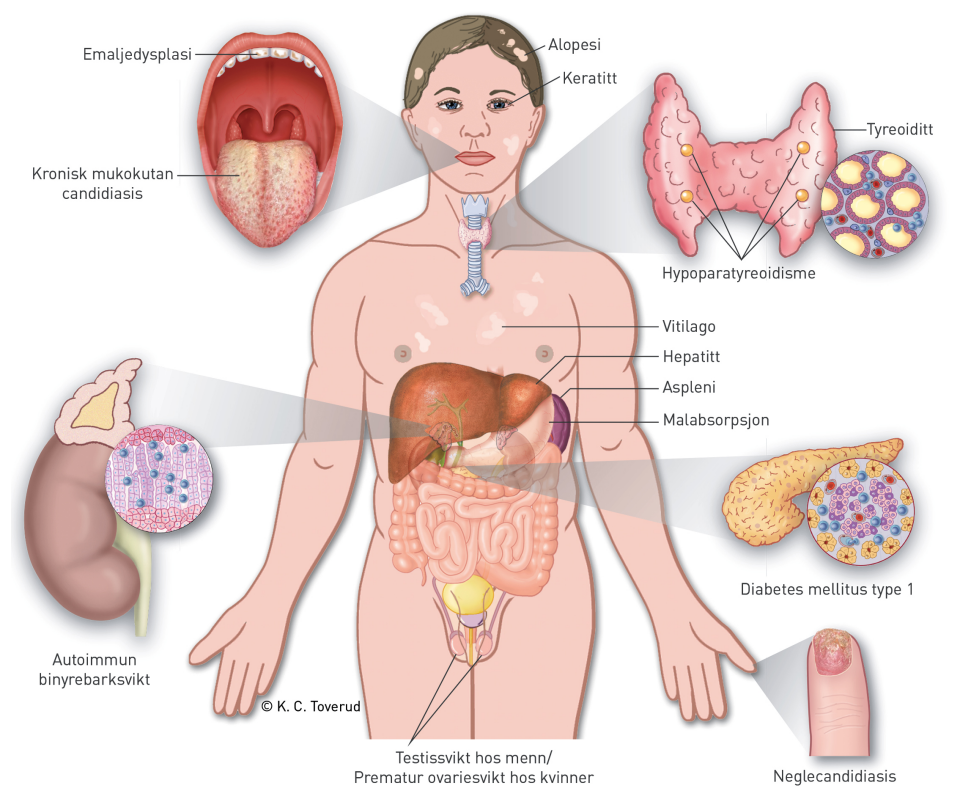

Figur 1 Kliniske manifestasjoner som kan forekomme ved autoimmunt polyendokrint syndrom type 1 (APS-1). Figuren er gjengitt etter tillatelse fra forfattere og Tidsskriftet (7).

Diagnosen autoimmunt polyendokrint syndrom type 1 stilles ved at pasienten oppfyller to av de tre kriteriene i triaden $(15,18)$. Dersom et søsken har fått påvist syndromet, kan diagnosen stilles med ett av kriteriene i triaden (7). Med bakgrunn i den variable presentasjonen av symptomer samt progredierende forløp, bør det være lav terskel for utredning dersom en pasient har ett eller flere av symptomene i den klassiske triaden. Dette gjelder både barneleger og tannleger som behandler barn med residiverende mukokutan candidiasis eller tannemaljehypoplasi. Diagnosen kan være vanskelig på grunn av den varierende presentasjonen. Fordi over $95 \%$ av pasientene har autoantistoffer mot interferon (INF)- $\omega$ eller INF- $\alpha(11,19,20)$, kan måling av disse autoantistoffene være en nyttig screeningtest (9). Analysen er tilgjengelig ved Haukeland universitetssjukehus. Endelig diagnose stilles ved sekvensering av AIRE-genet (9).

Det finnes ingen kurativ behandling for autoimmunt polyendokrint syndrom type 1 . Behandlingen er symptomatisk med substitusjon av affiserte hormonakser og håndtering av komplikasjoner $(9,16)$. Noen av manifestasjonene kan dels være alvorlige og i verste fall dødelige, som autoimmun hepatitt og bronkiolitt. Det er i tillegg viktig å behandle mukokutan candidiasis, da det ubehandlet gir $\varnothing$ kt risiko for utvikling av plateepitelkarsinom (16).

\section{LITTERATUR:}

1. Scheffer IE, Berkovic S, Capovilla G et al. ILAE classification of the epilepsies: Position paper of the ILAE Commission for Classification and Terminology. Epilepsia 2017; 58: 512-21. [PubMed][CrossRef]

2. Bjurulf B, Klingenberg C, Heier I. Akuttveileder i pediatri: Feberkramper. Norsk barnelegeforening. https://www.helsebiblioteket.no/pediatriveiledere?key=149720\&menuitemkeylev1=6747\&menuitemk eylev2 $=6569$ Lest 15.4.2020.

3. Reigstad H. Natrium- og osmolalitetsforstyrrelsar. Norsk barnelegeforening. https://www.helsebiblioteket.no/pediatriveiledere?menuitemkeylev1 $=6747$ \&menuitemkeylev $2=6508$ \&key $=151044$ Lest 15.4.2020. 
4. Bjerknes R, Markestad T, Reigstad H et al. Akutte forstyrrelser i kalsiumbalansen. Norsk barnelegeforening.

https://www.helsebiblioteket.no/pediatriveiledere?menuitemkeylev1=6747\&menuitemkeylev2=6508 \&key $=148912$ Lest $15 \cdot 4 \cdot 2020$.

5. Nardone R, Brigo F, Trinka E. Acute symptomatic seizures caused by electrolyte disturbances. J Clin Neurol 2016; 12: 21-33. [PubMed][CrossRef]

6. Myhre AG, Bjerknes R. Akuttveileder i pediatri: Binyrebarksvikt. Norsk barnelegeforening. https://www.helsebiblioteket.no/pediatriveiledere?menuitemkeylev1 $=6747$ \&menuitemkeylev2 $=6508$ $\& \mathrm{key}=150325$ Lest $15 \cdot 4.2020$.

7. Bruserud $\emptyset$, Husebye ES. En mann i zo-årene med diabetes og vitiligo. Tidsskr Nor Legeforen 2015; 135: 763-6. [PubMed][CrossRef]

8. Cheng M, Anderson MS. Thymic tolerance as a key brake on autoimmunity. Nat Immunol 2018; 19: 659-64. [PubMed][CrossRef]

9. Husebye ES, Anderson MS, Kämpe O. Autoimmune polyendocrine syndromes. N Engl J Med 2018; 378: 1132-41. [PubMed][CrossRef]

10. Yang S, Fujikado N, Kolodin D et al. Immune tolerance. Regulatory T cells generated early in life play a distinct role in maintaining self-tolerance. Science 2015;348: 589-94. [PubMed][CrossRef]

11. Bruserud $\emptyset$, Oftedal BE, Landegren $N$ et al. A longitudinal follow-up of autoimmune polyendocrine syndrome type 1. J Clin Endocrinol Metab 2016; 101: 2975-83. [PubMed][CrossRef]

12. Wolff AS, Erichsen MM, Meager A et al. Autoimmune polyendocrine syndrome type 1 in Norway: phenotypic variation, autoantibodies, and novel mutations in the autoimmune regulator gene. J Clin Endocrinol Metab 2007; 92: 595-603. [PubMed][CrossRef]

13. Zlotogora J, Shapiro MS. Polyglandular autoimmune syndrome type I among Iranian Jews. J Med Genet 1992; 29: 824-6. [PubMed][CrossRef]

14. Betterle C, Greggio NA, Volpato M. Clinical review 93: Autoimmune polyglandular syndrome type 1. J Clin Endocrinol Metab 1998; 83: 1049-55. [PubMed][CrossRef]

15. Neufeld M, Maclaren N, Blizzard R. Autoimmune polyglandular syndromes. Pediatr Ann 1980; 9: 154-62. [PubMed][CrossRef]

16. Husebye ES, Perheentupa J, Rautemaa R et al. Clinical manifestations and management of patients with autoimmune polyendocrine syndrome type I. J Intern Med 2009; 265:514-29. [PubMed][CrossRef]

17. Perheentupa J. Autoimmune polyendocrinopathy-candidiasis-ectodermal dystrophy. J Clin Endocrinol Metab 20o6; 91: 2843-50. [PubMed][CrossRef]

18. Ahonen P, Myllärniemi S, Sipilä I et al. Clinical variation of autoimmune polyendocrinopathycandidiasis-ectodermal dystrophy (APECED) in a series of 68 patients. N Engl J Med 1990;322: 1829-36. [PubMed][CrossRef]

19. Orlova EM, Sozaeva LS, Kareva MA et al. Expanding the phenotypic and genotypic landscape of autoimmune polyendocrine syndrome type 1. J Clin Endocrinol Metab 2017; 102:3546-56.

[PubMed][CrossRef]

20. Meager A, Visvalingam K, Peterson P et al. Anti-interferon autoantibodies in autoimmune polyendocrinopathy syndrome type 1. PLoS Med 2006; 3: e289. [PubMed][CrossRef]

Publisert: 4. juni 2020. Tidsskr Nor Legeforen. DOI:10.4045/tidsskr.19.0737

Mottatt 13.11.2019, første revisjon innsendt 30.1.2020, godkjent 15.4.2020.

(C) Tidsskrift for Den norske legeforening 2020. Lastet ned fra tidsskriftet.no 